\title{
JobStart
}

\section{Part 8 \\ Staying on the Job Once You Are Hired}

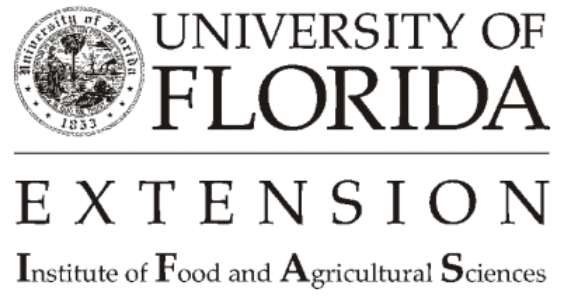




\section{Some Rules of Conduct}

It is easy to think that being hired is the last step in the job winning process, but nothing could be any further from the truth. Everyday 12,000 people are fired in the United States. Being hired only means that the employer is willing to take a risk on you; that you have impressed the employer with your skills, background, education, and interview performance; and that the employer wants to see if you are just as good on the job as you appeared in the interview. The tool most employers use during this trial time is the Probationary Period. You must meet the expectations of the employer during this Probationary Period or you may find yourself back in the job search world once again.

The number one reason people are fired from their jobs is poor attendance. Either they miss too much work or arrive late for work too often. There are many other reasons that can cause an employer to fire you as well. That is why a list of rules and expected behaviors is needed. Some employers provide an employee's handbook to new employees that usually lists some of these rules. Some handbooks even go so far as to outline just what type of disciplinary actions will be taken for each type of behavior. If you are given one of these handbooks, don't stash it in a desk, reading only the number of holidays and vacation days coming to you. Read the entire handbook from cover to cover. It might just save your job one day.

The following list is made up of rules, expected behaviors, and some suggested behaviors that will help you be more successful in your new job.

1. Arrive at work on time, preferably early.

2. Never leave work right at quitting time. Wait a few minutes.

3. Always demonstrate proper hygiene and follow the company's dress code.

4. Always clean up after yourself.

5. Never leave work for someone else to do.

6. Listen to your supervisor when receiving instruction.

7. Never engage in gossip.

8. Learn your job in a timely manner.

9. Avoid wasting materials.

10. Always be polite and use good manners.

11. Avoid getting into arguments with coworkers 
12. Take control of your emotions at work.

13. Never be sarcastic when talking at work.

14. Never tell dirty jokes or play dirty tricks at work.

15. Keep sex out of the work place at all times.

16. Always stay busy and hard at work.

17. Never use profanities at work.

18. Avoid joining cliques.

19. Avoid discussing salaries with coworkers.

20. Be honest, sincere, and cheerful when dealing with others at work.

\section{Work Attitudes}

Mary Jo Johnson is a secretary at First National Bank. She is married with two children and is very active with the many organizations in her community. While Mary's husband makes enough money to pay their bills and put some aside for retirement, Mary feels that she should work so that they can afford the some of the luxuries in life like summer vacations, a ski boat for the family, nice clothes, nice cars, and sometimes some jewelry for herself.

Mary works directly under Mr. Currency, First National Bank's senior loan officer. Mr. Currency has not been quite satisfied with Mary since hiring her four months earlier. He has noticed that she arrives at work just barely on time and is out the door and heading toward the parking lot as the clock strikes five o'clock everyday. She always takes her breaks at her convenience whether she is in the middle of something or not. And while she is keeping up with the workload he has given her, Mr. Currency has noticed that once she has finished an assignment she doesn't occupy herself until he gives her more work to do. Once when Mr. Currency had to meet a deadline he asked her to stay late one evening to assist, but she told him that she was unable to because she had to go home and prepare dinner for the family.

Mr. Currency is also disappointed with Mary's interaction with the clients. While she is not rude or disrespectful she is blunt and not so warm when talking to them. This is something that Mr. Currency cannot allow to continue much longer because it will affect the business in the loan department.

Mary's six month probationary period is close to ending and Mr. Currency will have to do an evaluation of her performance and either recommend she continue or discontinue her employment with the bank. 
What should Mr. Currency do? Does Mary have a bad attitude? Do you think that because Mary doesn't need her job to pay bills she doesn't care as much about it? What could Mary do to save her job?

One of the first things an employer looks for in an employee is their attitude. An employee's attitude affects performance, work relationships, and overall morale in a department or company. Mary's attitude could potentially hurt Mr. Currency's and his department's performance. Her attitude could also cost her a job.

Below are some traits that exemplify a positive attitude at work.

- $\quad$ Enthusiasm

- $\quad$ Initiative

- Willingness to learn

- Cooperation

- Dependability

- $\quad$ Ability to accept criticism

- Honesty

- Willingness to follow directions

- Loyalty

Which of the above traits is Mary lacking at work?

Our own values, goals, and special circumstances affect our attitudes at work and the traits we exhibit there. How do you think Mary's special circumstances and goals might be affecting her attitude? How do your values, goals, and special circumstances affect your attitude towards work? What can you do to overcome any weaknesses you might have?

\section{Those Difficult People}

Even if we have the best work attitude and are following every rule and suggested behavior in order to be successful at work, there is still one situation that is capable of undoing even the best of employees. It is dealing with difficult people. Sometimes difficult people can bring out behaviors we never knew 
existed in us. They can arouse emotions that cause us to behave irrationally and lose control. However, if you realize ahead of time just who these people are you can avoid getting caught up in the trap. You can learn to deal with them professionally.

There are many types of difficult people we must learn to contend with in the work place; too many to list, so for now let's put them into a few main categories. They are as follows.

\section{The Dominant Bully}

In many work settings there is a struggle to get to the top of the organizational hierarchy. Some individuals take this struggle a little too far. They are pushy. They are back-stabbing. They will stop at nothing to get to the top and heaven help anyone, including you, who gets in their way. The best thing to do once you have identified this type of individual is to avoid getting caught up in a competition with them. Maybe you could offer them a bit of praise to throw them off guard. Try to communicate to them that you wish nothing but the best for them and are not a threat. Then let them go on their merry way.

\section{The Impulsive}

These types of workers are always in a hurry. They are frantic and often act impulsively without any forethought or planning. They seldom finish projects that they have started and are quick to cut you off in conversations. The best method for dealing with these types of workers is to be gentle with them, offering words of encouragement. If they cut you off in conversations you need to emphasize your point without getting too loud. Sometimes it is just best to let them alone to make their own mistakes.

\section{The Defender of the Territory}

In every company there is a person who has marked off a territory that is off-limits to everyone else, sometimes even the boss. It is a turf war. When they feel that they are threatened they very often strike out to defend their turf. The best way to deal with this type of person is to respect their territory and take it seriously. Never get into a confrontation over it. Find a way to gain access to the territory by polite means if possible. Be non-threatening. Always acknowledge that the person has a right to the territory and in that way they should not perceive you as someone trying to take it from them.

\section{The Office Romancer}

There will always be office romances. It is a hard thing to control when members of the opposite sex work together. However, it is something that is not recommended. When the office romancer approaches they will bring with them all the charm they can muster. They will use compliments and flirtatious behaviors to try and woo you. The best way to handle this is to state at the outset that you are not interested and that you expect the flirtatious behavior to stop. Of course you need to be tactful when 
doing this so as not to create any hard feelings. If the behavior continues after this it becomes more of a matter of harassment, which should be dealt with quickly through proper channels.

\section{Dealing With Stress}

Stress is the tension caused by situations. It is estimated that $80 \%$ to $90 \%$ of all illnesses are related to stress. Work related stress can be caused by such things as too little time to accomplish a task, poor instructions, a lack of organization, etc. Stress can be self induced or induced by others. What is important is to recognize stress and to find ways to reduce it.

The following are some immediate signs of stress:

- $\quad$ Tensed muscles

- Increased perspiration

- $\quad$ Rapid pulse

- Tight stomach

- $\quad$ Nausea

- Chills
- $\quad$ Pounding heart

- $\quad$ Flushing of the face

- $\quad$ Light-headedness

- $\quad$ Shortness of breath

- $\quad$ Reduced ability to concentrate

\section{Some other symptoms of stress are:}

- $\quad$ Sleeping problems

- Fatigue

- Indigestion

- Headaches
- Loss of appetite

- Diarrhea

- Muscle pains

- Hives or rashes

Some long term disorders caused by stress are:

- Diabetes

- Ulcers

- Asthma

- Heart disease

- $\quad$ High blood pressure
- Bronchitis

- $\quad$ Arthritis

- Kidney disease

- Death

\section{Some psychological disorders caused by stress are:}
- $\quad$ Nightmares
- Loss of memory
- Anxiety
- Nervousness

$\begin{array}{ll}\text { - } & \text { Depression } \\ \text { - } & \text { Loss of motivation } \\ \text { - } & \text { Anger } \\ & \text { Paranoia }\end{array}$ 


\section{Stress can cause your job performance to suffer as well. It can:}

- $\quad$ cause absenteeism

- $\quad$ reduce the quality of work

- $\quad$ cause mood swings

- $\quad$ reduce ability to make decisions

- $\quad$ cause hostility toward other workers

- $\quad$ cause overreaction to mild work pressures

- $\quad$ cause a shirking of responsibilities

There are many ways that you can deal with stress, the most important of which is to lead a healthy lifestyle. People that deal with stress well have some of the same things in common. They keep a balance between their work life and their home life. They welcome new situations and challenges. They exercise regularly and eat a healthy diet. They keep a good sense of humor. They like their work and are active in pursuing success.

\section{The following are some tips that can help you deal with stress.}

1. Eat at least one hot, balanced meal a day.

2. Get seven to eight hours of sleep per night.

3. Give and receive affection regularly.

4. Have a family member or friend that you can talk to.

5. Exercise at least twice a week.

6. Eliminate tobacco products from your lifestyle.

7. Eliminate alcohol from your lifestyle.

8. Don't live beyond your means.

9. Get strength from your spiritual beliefs. 
10. Create a network of friends.

11. Involve yourself in social activities.

12. Do something fun at least twice a week.

13. Manage your time effectively.

14. Reduce your consumption of coffee.

15. Make some quiet time during the day.

16. Be a positive thinker.

17. Stand up for yourself.

18. Take time to relax and breathe deeply in stressful situations.

19. Picture yourself in wonderful setting while closing your eyes.

20. Ask yourself, "Will it matter in a year from now?"

\section{References}

Bernstein, A.J. \& Rozen, S.C. (1990). Dinosaur Brains: Dealing With All Those Impossible People at Work. New York: Ballentine Books.

Lareau, W. (1985). Conduct Expected: The Unwritten Rules for a Business Career. Clinton, NJ: New Win Publishing, Inc.

Shaw, C. \& Wolford, N. (1992). The Fact Workbook. Columbus, OH: The Ohio State University. 
This document is FY352, Part 8 of an 8 part series developed for the Department of Family, Youth and Community Sciences, Cooperative Extension Service, Institute of Food and Agricultural Sciences, University of Florida.

Revised version prepared for electronic publication November 2001 by Elizabeth B. Bolton, professor, community development, Department of Family, Youth and Community Sciences, Extension Cooperative Service, Institute of Food and Agricultural Sciences, University of Florida, Gainesville, 32611-0310.

Original version prepared for publication May 1997 by Elizabeth B. Bolton, professor, community development, Department of Family, Youth and Community Sciences and George O. Hack, assistant in Department of Family, Youth and Community Sciences, Extension Cooperative Service, Institute of Food and Agricultural Sciences, University of Florida, Gainesville, 32611-0310.

The Institute of Food and Agricultural Sciences is an equal opportunity/affirmative action employer authorized to provide research, educational information and other services only to individuals and institutions that function without regard to race, color, sex, age, handicap, or national origin. For information on obtaining other extension publications, contact your county Cooperative Extension Service office.

Florida Cooperative Extension Service/Institute of Food and Agricultural Sciences/University of Florida/Christine Taylor Waddill, Dean 